\title{
ACTIONS OF PROCAINE ON SPECIFIC NOCICEPTIVE CELLS IN LEECH CENTRAL NERVOUS SYSTEM ${ }^{1}$
}

\author{
JORGEN JOHANSEN, ${ }^{*}$ JAY YANG, $\ddagger$ AND ANNA L. KLEINHAUS $\ddagger^{2}$ \\ * Cold Spring Harbor Laboratory, Cold Spring Harbor, New York 11724 and $\ddagger$ Department of Neurology, Yale University School \\ of Medicine, New Haven, Connecticut 06510
}

Received August 5, 1983; Revised November 1, 1983; Accepted November 2, 1983

\begin{abstract}
The effects of the local anesthetic, procaine, on the electrophysiological properties of the leech neurons responding to nociceptive stimuli ( $\mathrm{N}$ cells) were examined in isolated segmental ganglia in Macrobdella.

In the $\mathrm{N}$ cell situated laterally in ganglia 7 to 19 , procaine produced a depolarization; whereas in the $\mathrm{N}$ cell situated medially, it caused a hyperpolarization. These changes in membrane potential were accompanied by a decrease in input resistance, persisted in solutions containing $20 \mathrm{mM} \mathrm{MgCl}_{2}$, and were reversible after drug washout.

The depolarization induced by procaine in the lateral $\mathrm{N}$ cell was abolished in $\mathrm{Na}$-free solutions. The hyperpolarization produced by procaine in the medial $\mathrm{N}$ cell persisted in low chloride solutions and was enhanced by about $30 \%$ when the $\mathrm{K}$ concentration was reduced to one-tenth of its control value. Therefore, it seems likely that an increase in the resting $K$ conductance was a contributing factor to this hyperpolarization.

Procaine greatly prolonged the action potential of the lateral but not the medial $\mathrm{N}$ cell. This effect was not solely a consequence of the membrane potential change produced by the drug.

Ganglia 5, 6, 20, and 21 contained two rather than four cells with $\mathrm{N}$-like properties. These neurons were $\mathrm{N}$-like by virtue of the shape of their action potential and their morphological similarities to the $\mathrm{N}$ cells found in ganglia 7 to 19 , as well as by their selective sensitivities to nociceptive mechanical stimulation of the skin. The cells in ganglia 5 and 6 responded to gut stimulation, as did the medial $\mathrm{N}$ cells in ganglia 7 to 19 .

The single $\mathrm{N}$-like cell in ganglia 5 and 6 responded to procaine like the medial $\mathrm{N}$ cells in ganglia 7 to 19. The cells in ganglia 20 and 21 responded like lateral $\mathrm{N}$ cells of ganglia 7 to 19 .

Leech ganglia contain two pairs of nociceptive $(\mathrm{N})$ cells that have similar functional, electrical, and morphological characteristics but differ in their chemosensitivity and antigenicity.
\end{abstract}

Several studies from this laboratory have dealt with the differential sensitivity to pharmacological agents of a well characterized group of neurons in the leech central nervous system. These studies showed that drugs known to block $\mathrm{Na}$ and $\mathrm{K}$ channels in other excitable membranes acted on the Retzius cells and on three sensory neurons in a similar way (Kleinhaus and Prichard, 1975, 1977a, 1979, 1983; Kleinhaus, 1980). The drugs' actions

\footnotetext{
${ }^{1}$ This work was supported by United States Public Health Service Grant 5-R01-NS18054-02 to A. L. K., a grant from the Danish National Science Research Council to J. J., and a grant from the Swebilius Trust Fund. We are very grateful to Dr. J. G. Nicholls for reading an earlier version of this manuscript. We are indebted to Hector Goico for excellent technical assistance and to Mr. Frank Esposito for his help in maintaining the electronic equipment.

${ }^{2}$ To whom correspondence should be addressed.
}

were cell-specific in a manner compatible with the hypothesis that particular neuronal functions are coupled to distinct sets of membrane conductances. While investigating the sensitivities of the same ensemble of neurons to procaine, we found that this drug acted differently on the resting membrane properties of certain closely related cells (Yang and Kleinhaus, 1982). Several workers have reported that the bilateral pairs of nociceptive $(\mathrm{N})$ cells situated in ganglia 7 to 19 (Nicholls and Baylor, 1968) differ with respect to their receptive fields (Blackshaw et al., 1982) and chemosensitivity (Sargent et al., 1977).

The recent successful application of immunohistochemical techniques to leech neurobiology has brought some new insight into the molecular organization of this "simple" nervous system (Zipser and McKay, 1981; Zipser, 1982). Most recently, work by McKay et al. (1982) 
showed that, in addition to distinguishing among groups of neurons of different modalities, some antibodies were specific for individual neurons within a subset of cells sharing a modality. In particular, $\mathrm{N}$ cells were subdivided in cells of the medial and the lateral types.

The experiments described in this paper show that the $\mathrm{N}$ cells, which can be distinguished by their chemosensitivity to transmitters and their selective affinity for monoclonal antibodies, also have conductance populations which respond differently to procaine.

\section{Materials and Methods}

For the pharmacological experiments, segmental ganglia were dissected from Macrobdella decora and fixed with magnet-stabilized pins to the bottom of a simple chamber on a microscope slide. The nociceptive cells extensively studied by Nicholls and Baylor (1968) and Blackshaw et al. (1982) were used in this study. There are two such neurons in each half of segmental ganglia 7 to 19 ; one is situated medially and the other laterally with respect to the longitudinal axis. They are labeled $\mathrm{N}_{\text {med }}$ and $\mathrm{N}_{\text {lat }}$ cells throughout this paper. Cell identification was done by anatomical (cell location), physiological (action potential shape and receptive field determination using skin preparations) (Nicholls and Baylor, 1968; Blackshaw et al., 1982), and morphological (HRP injection) criteria.

Solutions and drugs. The standard Ringer solution used in these experiments contained (millimoles per liter): $\mathrm{NaCl}(120), \mathrm{KCl}(4), \mathrm{CaCl}_{2}$ (2), glucose (10), and either tris(hydroxymethyl)aminomethane (Tris) (10) or $N$-2-hydroxyethyl-piperazine- $N^{\prime}$-2-ethanesulfonic acid (HEPES) (10) with sufficient $10 \mathrm{~N} \mathrm{HCl}$ or $\mathrm{NaOH}$ to achieve a $\mathrm{pH}$ of 7.4. Procaine-HCl (Sigma) was dissolved in this solution, and any resulting $\mathrm{pH}$ change was corrected as needed. Low $\mathrm{Na}$ solutions were usually made by mixing normal Ringer in appropriate proportions with a solution having the same constituents except for replacement of $\mathrm{NaCl}$ with $120 \mathrm{mM}$ choline chloride or 240 mM sucrose. Low chloride solutions were made by substituting the propionate or acetate salts of $\mathrm{Na}, \mathrm{K}$, and Ca for the chloride salts.

Electrophysiological apparatus. Recording microelectrodes were pulled from 1-mm Ultradot glass (Haer); when filled with $4 \mathrm{M}$ potassium acetate or $3 \mathrm{M}$ potassium chloride their DC resistance was between 20 and 40 megohms. A ceramic bridge connected the solutions bathing the ganglia to a pool saturated with $\mathrm{KCl}$. This and the microelectrode were connected through $\mathrm{Ag}-\mathrm{AgCl}$ electrodes to the input stage of the recording and stimulating system, which consisted of a Dagan 8100 electrometer. Membrane resistance measurements were made through the recording microelectrode via an active bridge circuit. Bridge balance was continuously monitored and adjusted. Permanent recording was done with a PDP-8 computer system which digitalized the traces at $23 \mathrm{kHz}$ and stored them on magnetic media for subsequent reproduction on an incremental plotter. In some cases (Fig. 5) voltage traces were displayed on a storage oscilloscope and photographed with a Polaroid camera. Simultaneous monitoring of the entire experiment was done on a Hewlett-Packard $7402 \mathrm{~A}$ pen recorder. Com- mand waveforms and triggering signals were obtained from a multichannel digital stimualtor (W. P. Instruments 800 series).

Procedure. Ganglia were studied in a chamber fashioned on a microscope slide so as to have an adjustable volume which could be as little as $0.1 \mathrm{ml}$. Solutions flowed into the chamber at a gravity-driven rate of approximately $1.5 \mathrm{ml} / \mathrm{min}$ and were removed by suction. A sixway valve allowed rapid change of solutions without interruption of flow. All experiments were done at room temperature (19 to $24^{\circ} \mathrm{C}$ ).

Horseradish peroxidase injection. Horseradish peroxidase (Sigma type VI)(HRP) was injected by pressure into the neurons from beveled electrodes (Anderson et al., 1974) pulled from $1.2-\mathrm{mm}$ borosilicate glass, filled with a $3 \% \mathrm{HRP}$ solution in $0.1 \mathrm{M} \mathrm{KCl}$; fast green was added to the solution for visual confirmation of successful ejection of the enzyme. These HRP electrodes had resistances of 50 to 60 megohms. Approximately $2 \mathrm{hr}$ after injection, the ganglia were prepared for light microscopy, reacted with benzidine, and viewed as a whole mount in Depex (BDH Chemicals) following the procedure of Muller and McMahan (1976).

\section{Results}

Procaine actions on membrane potential of $N$ cells in ganglia 7 to 19. The characteristic actions of procaine on the membrane potential of the $\mathrm{N}_{\text {lat }}$ and $\mathrm{N}_{\text {med }}$ cells are illustrated in Figure 1. The ink traces are from $\mathrm{N}$ cells in midbody ganglia exposed to $10 \mathrm{mM}$ procaine for the period of time bracketed by the two arrows. Both depolarization $\left(\mathrm{N}_{\text {lat }}\right)$ and hyperpolarization $\left(\mathrm{N}_{\text {med }}\right)$ were accompanied by decreased input resistance; all the changes were reversed between 8 and $10 \mathrm{~min}$ following washout in normal Ringer. Procaine's effects on membrane potential were not mediated through synaptic pathways since they persisted in solutions containing $20 \mathrm{mM}$ $\mathrm{MgCl}_{2}$, which is known to block chemical synapses in the leech (Stuart, 1970). As shown in the graph below the traces, procaine-induced depolarization and hyperpolarization were dose-dependent. The points on the graph are from measurements taken 10 min after drug application, i.e. at steady state. Each represents mean \pm $\mathrm{SE}$ for four to eight cells except for the 0.1 and $0.3 \mathrm{mM}$ points for the $\mathrm{N}_{\text {lat }}$, which are from two cells. The scales for the ordinates are different for both cell types. The change in input resistance in the $\mathrm{N}_{\text {med }}$ cell was sometimes small. The magnitude of conductance change which was actually measured may depend on the properties of the cable lying between the procaine-sensitive site and site of recording at the soma.

Ionic basis of the membrane potential changes in $N$ cells in ganglia 7 to 19 . Figure 2 is a record from an $\mathrm{N}_{\text {lat }}$ cell from the midbody region showing that removal of $\mathrm{Na}$ (middle trace) abolished the depolarizing response to 5 mM procaine (top trace). Approximately 2 min after the drug-containing solution flowed in the chamber, the membrane hyperpolarized by about $3 \mathrm{mV}$ and the input resistance decreased. Three minutes after drug removal, the membrane potential and input resistance returned toward control levels. This observation suggests that both depolarization and hyperpolarization normally co- 

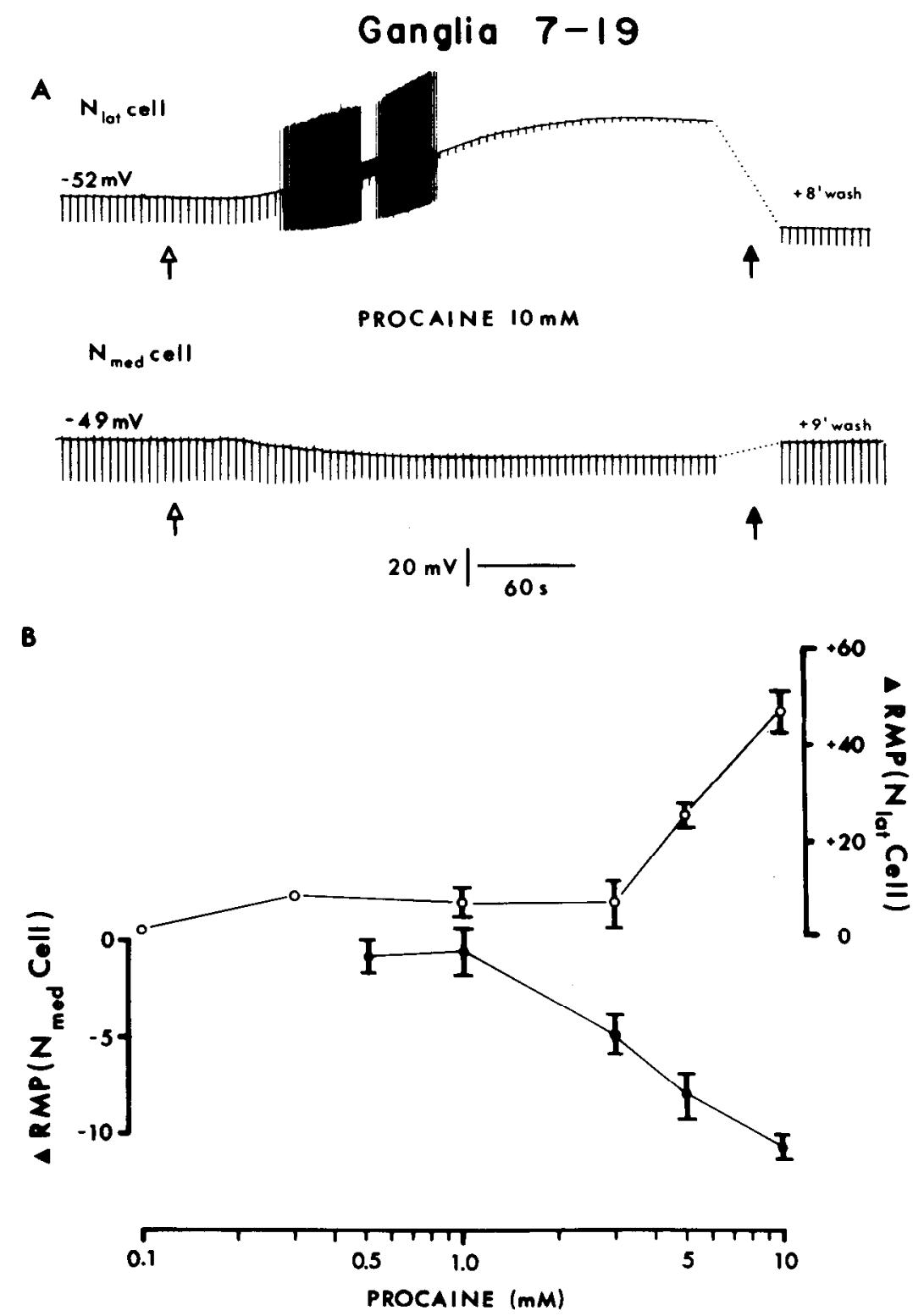

Figure 1. Effects of procaine on resting membrane properties $(R M P)$ of $\mathrm{N}$ cells in midbody ganglia. $A$, Traces are continuous intracellular records taken from an $\mathrm{N}_{\text {lat }}$ cell (top) and an $\mathrm{N}_{\text {med }}$ (bottom) before, during, and after exposure to $10 \mathrm{mM}$ procaine-HCl. During the procaine-induced changes in membrane potential, imput resistance decreased as indicated by the reversible fall in amplitude of the electrotonic potentials. Drug was present between the arrows. The amplitude of action potentials was truncated by the low frequency response of the penwriter. $B$, Graphs represent the doseresponse curve for the change in membrane potential produced by procaine in $\mathrm{N}_{\text {lat }}$ (open circles) and $\mathrm{N}_{\text {med }}$ (solid circles); positive changes on the ordinate indicate depolarizations. Note the different scales for the ordinates. Data are steady-state mean $( \pm S E)$ values obtained for four to eight cells at each concentration; data points without $\mathrm{SE}$ bars are from two cells.

incided in the $\mathrm{N}_{\text {lat }}$ neurons and that the large depolarization produced by the drug in Na-containing solutions masked the smaller hyperpolarization. That the absence of depolarization in the absence of $\mathrm{Na}$ was not due to desensitization of the neuronal membrane is shown in the bottom panel, where a third application of procaine after reintroduction of $120 \mathrm{~mm} \mathrm{NaCl}$ produced a depolarization of the same magnitude as the first (top panel).
The third application of procaine occurred before full recovery, hence the absence of action potentials during the depolarizing response. Current/voltage curves were obtained from two $\mathrm{N}_{\text {lat }}$ cells in the presence and absence of procaine. The conductance increase observed in this cell type during the procaine-induced depolarization was much larger than that observed at the same membrane potential in the absence of the drug. 
Replacing chloride with equimolar concentrations of propionate did not significantly change the amplitude of the hyperpolarization produced by procaine in the $\mathrm{N}_{\text {med }}$ neurons; the mean increase in membrane potential caused by procaine (10 $\mathrm{mm})$ in three cells in Ringer containing $10 \mathrm{mM}$ chloride was $8 \mathrm{mV}$ as compared to 10 $\mathrm{mV}$ for the same cells in normal Ringer. Therefore, it seems unlikely that the hyperpolarization in this cell type resulted from an increase in chloride conductance $(\mathrm{gCl})$. These results were obtained both with $\mathrm{KCl}$ and $\mathrm{K}$ acetate electrodes. In solutions containing one-tenth of the normal $\mathrm{K}$ concentration, the mean hyperpolarization produced by procaine $(10 \mathrm{mM})$ in another group of $\mathrm{N}_{\text {med }}$ cells was $18 \mathrm{mV}(n=4)$ as compared to $12 \mathrm{mV}$ in normal $\mathrm{K}$-Ringer. The mean membrane potential of the cells in $0.4 \mathrm{mM} \mathrm{K}$ was $-42.5 \mathrm{mV}$. This represents an approximate depolarization of $2 \mathrm{mV}$ when compared to the mean membrane potential recorded in solutions containing 4 $\mathrm{mM} \mathrm{K}$. The difference between the two values was not significant. In the Retzius cell other workers (J. W. Deitmer and W. R. Schlue, manuscript in preparation) observed a $3-\mathrm{mV}$ depolarization due to partial inhibition of the Na pump when going from $4 \mathrm{mM}$ to $0.2 \mathrm{mM}[\mathrm{K}]_{\mathrm{o}}$. The mean hyperpolarization produced by $10 \mathrm{~mm}$ in procaine these two groups in control Ringer was within the range of values summarized in Figure 1. It seems likely that a change in another conductance (presumably $\mathrm{Na}$ ) may contribute to the phenomenon. We were not able to

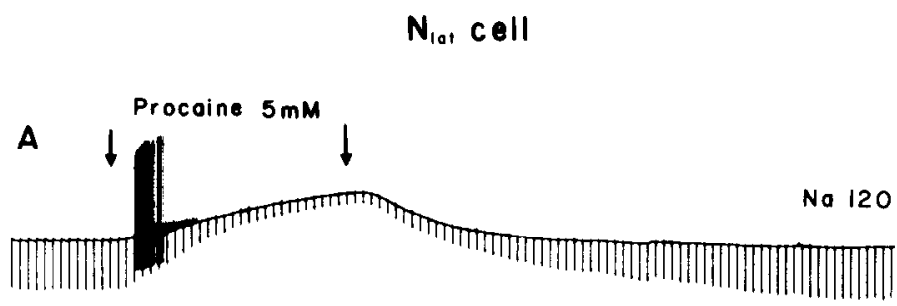

B

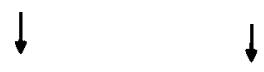

NoO

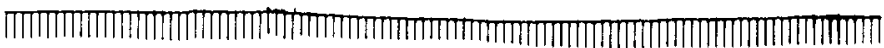

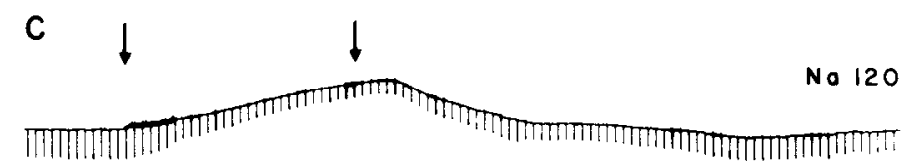

$$
20 \mathrm{mV} \mid \frac{}{60 \mathrm{~s}}
$$

Figure 2. Effect of $\mathrm{Na}$ replacement on $\mathrm{N}_{\text {lat }}$ response to procaine. Traces are the continuous intracellular record taken from an $\mathrm{N}_{\text {lat }}$ cell during three consecutive exposures to $5 \mathrm{~mm}$ procaine. A, Typical depolarization and fall in input resistance produced by short exposure to drug in control Ringer were almost entirely abolished in Na-free (choline substitution) solution $(B) . C$, After reintroduction of $\mathrm{Na}$ into the medium, the cells' response to a third exposure to procaine returned toward the control level.

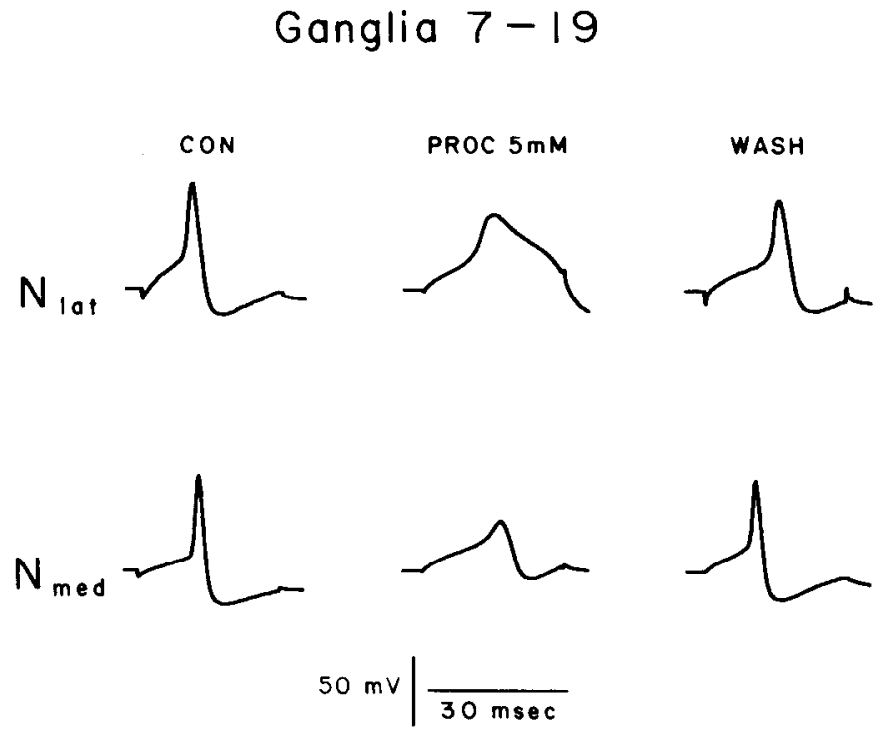

Figure 3. Effect of procaine ( $P R O C)$ on N cells action potential. Action potentials recorded in $\mathrm{N}_{\text {lac }}$ (top row) and $\mathrm{N}_{\text {med }}$ (bollom row) cells in two ganglia from the midbody region before, during, and after exposure to $5 \mathrm{~mm}$ procaine. Note the typical, reversible fall of action potential amplitude produced by procaine in both cell types and the prolongation of action potential of the $\mathrm{N}_{\text {lat }}$ cell. Traces in this figure and in Figures $6 B$ and $7 B$ were made by an incremental plotter from digitized data. $C O N$, control; WASH, wash period.

reverse the procaine-induced hyperpolarization by passing current through the microelectrode; there are several possible reasons for this failure (see the "Discussion").

Differential effect of procaine on $N_{\text {Med }}$ and $N_{\text {lat }}$ action potentials. Figure 3 illustrates the effects of $5 \mathrm{~mm}$ procaine on the action potential of $\mathrm{N}_{\text {lat }}$ and $\mathrm{N}_{\text {med }}$ cells situated in the midbody ganglia ( 7 to 19 ). During exposure to procaine, the action potential of the $\mathrm{N}_{\text {lat }}$ cell greatly increased in duration (top row); this prolongation occurred during the depolarizing phase of the response and was dose-dependent. Restoring the membrane potential to its predrug level did not shorten the action potential duration of the $\mathrm{N}_{\text {lat }}$ once it was prolonged by the drug. Similarly, depolarizing current injections did not prolong the action potential of the $\mathrm{N}_{\text {med }}$ during procaine exposure. In addition to its effect on action potential duration, procaine reduced the amplitude and rate of depolarization of the action potential in both cell types in a dosedependent fashion, as in other excitable membranes (Ritchie and Greene, 1980; Yang and Kleinhaus, 1982). Procaine's effects on the action potential were completely reversible (third set of traces, top and bottom rows).

Morphological identification of $N$ cells. The top two camera lucida tracings in Figure 4 are from the midbody region (ganglia 7 to 19) and are typical examples of the $\mathrm{N}_{\text {lat }}$ and $\mathrm{N}_{\text {med }}$ neurons found in Macrobdella. Their branching pattern is very similar to that of the homologous cells in Hirudo medicinalis, a closely related species, the morphology of which was first described by Muller and McMahan (1976). The bottom two drawings are from $\mathrm{N}$ cells located in a sex ganglion and ganglion 21 , respectively. These cells' processes distribute themselves along the same lines. Ganglia 20 and 21 are smaller than the 


\section{Ant}
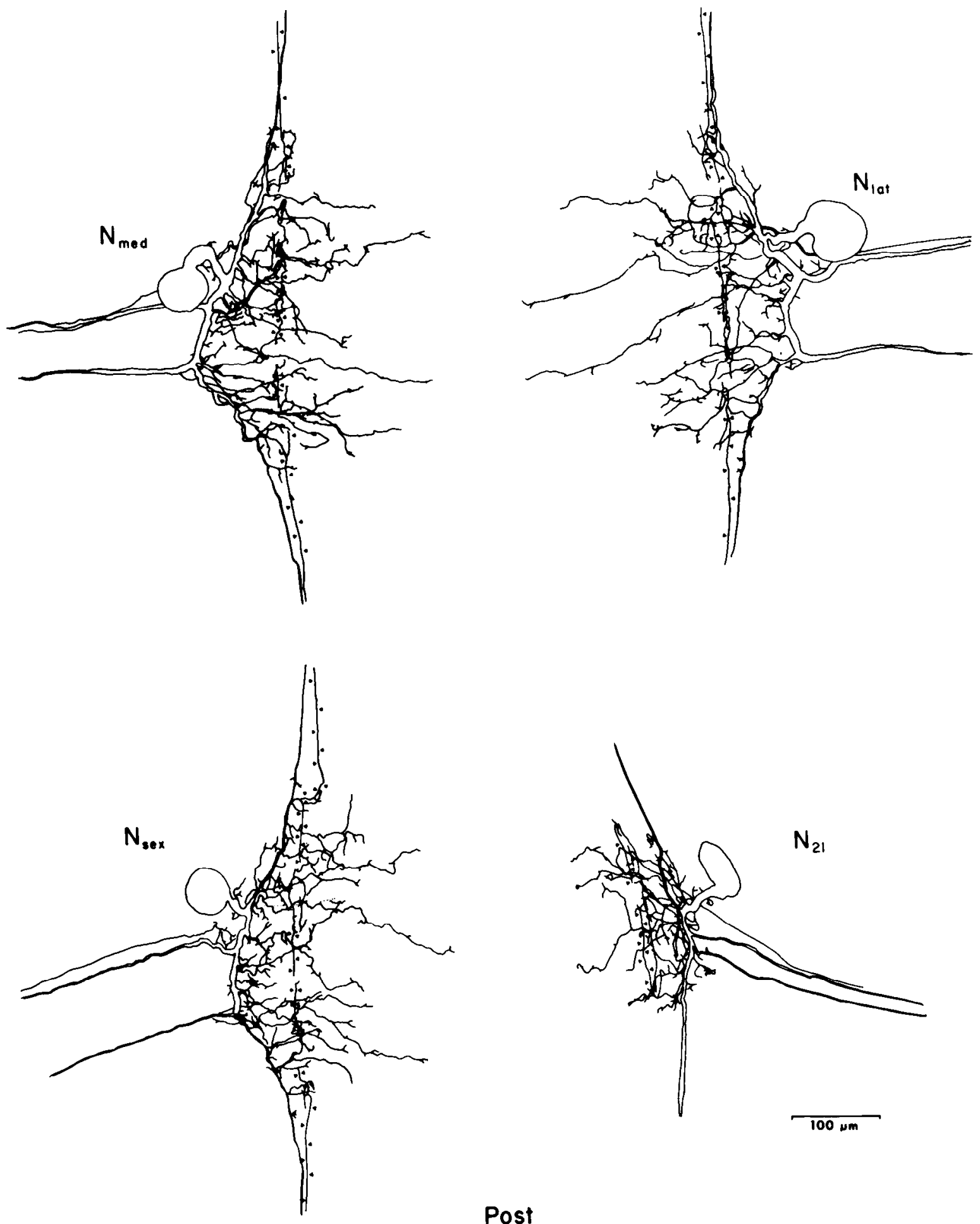

Post

Figure 4. Branching patterns of four $\mathrm{N}$ cells injected with HRP. Traces are camera lucida drawings from $\mathrm{N}_{\text {lat }}, \mathrm{N}_{\text {med, }}, \mathrm{N}_{\text {sex }}$, and $\mathrm{N}_{21}$ cells injected with HRP and developed with benzidine. Small arrowheads indicate the juncture of fine tributaries situated in a plane dorsal to the plane of the main branches as they proceed toward anterior (Ant) and posterior (Post) connectives. Note multiple small axons exiting ganglia via the anterior roots next to the main axon.

other ganglia by about one-third, hence the arborizations appear to be less numerous. Aside from this size difference, branching patterns of these four cell types are similar enough to be of no value in distinguishing one from another. In all four cell types, in addition to the main branching pattern, there is a set of fine processes running along the left-right axis. These join in several thin longitudinal processes running in parallel to the 
anterior-posterior axis in a plane more dorsal than the primary axons. These tributaries, identified in the camera lucida drawings by black arrowheads, often send processes out into both connectives. The main axon in the $\mathrm{N}$ cells of the midbody region of Hirudo splits into two branches which exit the ganglion via the anterior and posterior roots, but it is not unusual to find as many as three additional processes leaving the ganglion through the anterior root in Macrobdella.

Physiological characterization of $N$ cells. The $\mathrm{N}$ cells (lateral and medial) in ganglia 7 to 19 and those in ganglia $5,6,20$, and 21 responded with bursts of action potentials when the skin of the body wall was pinched with forceps. The action potential of the single N-like cells in ganglia $5,6,20$, and 21 had the characteristic shape of $\mathrm{N}$ cells (Nicholls and Baylor, 1968) of the midbody region. Typical physiological responses to mechanical stimulation of the skin are illustrated in Figure 5 for an $\mathrm{N}_{\text {lat }}$ (uppermost left trace), an $\mathrm{N}_{\text {sex }}$ (uppermost right trace), and an $\mathrm{N}_{20}$ (lower left trace). In addition to the usual peripheral sensory field, the $\mathrm{N}_{\text {med }}$ was sensitive to pinching of the gut wall (left trace, second row). This additional visceral field was first reported for the $\mathrm{N}_{\text {med }}$ cells in Hirudo (Blackshaw et al., 1982). The single N-
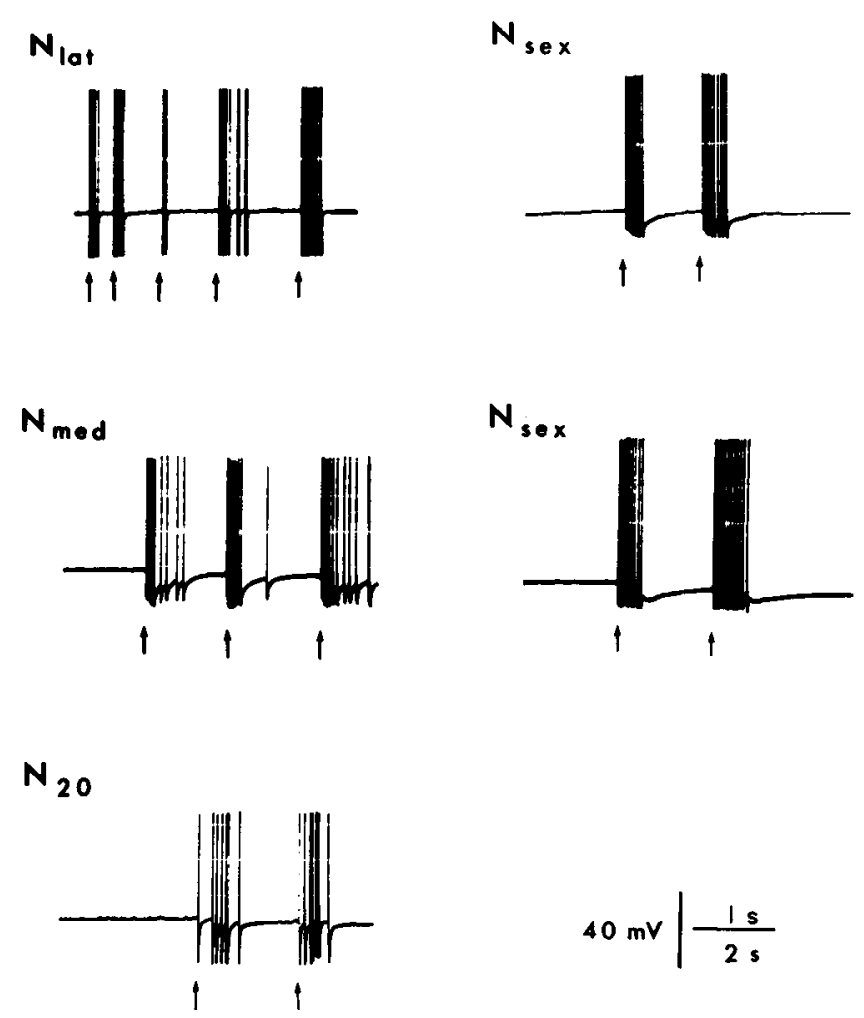

Figure 5. Responses of various $\mathrm{N}$ cells to stimulation of the skin and the viscera. Traces are intracellular bursts of action potentials recorded in an $\mathrm{N}$ cell from ganglia 7 to $19, \mathrm{~N}_{\text {mid }}$ (upper left), in $\mathrm{N}_{\mathrm{sex}}$ (upper right), and in $\mathrm{N}_{20}$ (lower left) following stimulation of the skin. Pinching the gut lining evoked high frequency discharges in the $\mathrm{N}_{\text {med }}$ (middle left) from ganglia 7 to 19 and from the $\mathrm{N}_{\text {sex }}$ (middle right). Small arrows indicate the beginning of the stimulus. The amplitude calibration is valid for all traces; the time calibration is $2 \mathrm{sec}$ for the upper left trace and $1 \mathrm{sec}$ for the others. Traces are reproduced from oscilloscope photographs.
Ganglion 5 NColl

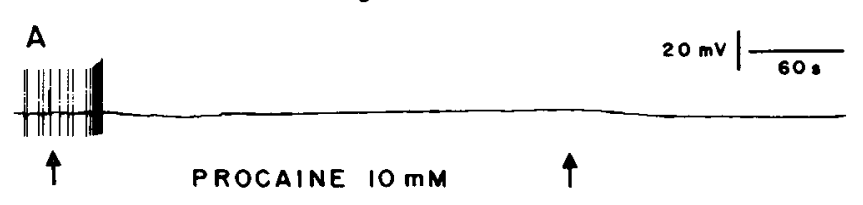

B

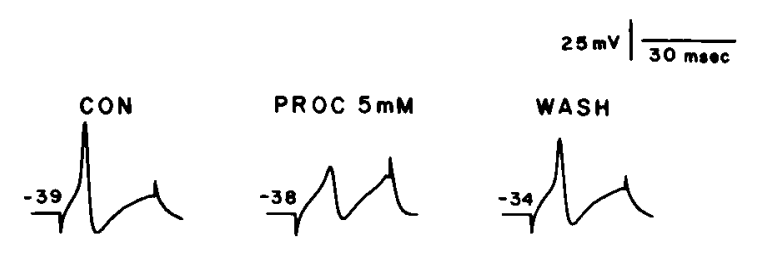

Figure 6. Procaine (PROC) actions on single N cell in ganglion 5. $A$, Intracellular record from single $\mathrm{N}$ cell in ganglion 5 before, during, and after exposure to $10 \mathrm{~mm}$ procaine; during procaine exposure there was little change in membrane potential, but spontaneous firing ceased. $B$, In another $\mathrm{N}$ cell, $5 \mathrm{~mm}$ procaine sharply reduced the amplitude of the action potential. Note that the calibrations scales for $A$ and $B$ are different. $C O N$, control; $W A S H$, wash period.

\section{Ganglion 20 NCell}

A

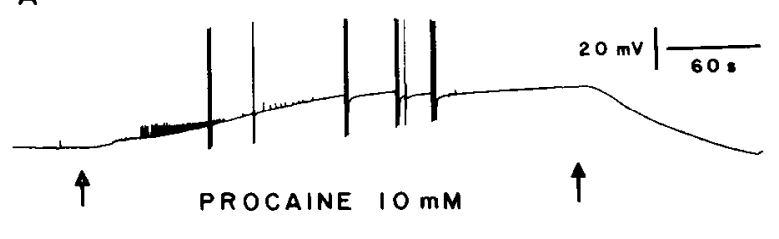

B

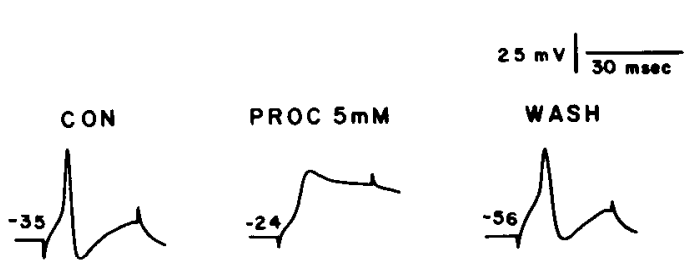

Figure 7. Procaine $(P R O C)$ actions on single $\mathrm{N}$ cell in ganglion $20 . A, 10 \mathrm{mM}$ procaine produced a $32-\mathrm{mV}$ depolarization which reversed upon washout (second arrow). $B$, Action potential recorded during $11-\mathrm{mV}$ depolarization produced by $5 \mathrm{~mm}$ procaine in another preparation was prolonged and exhibited a plateau similar to that of the $\mathrm{N}_{\text {lat }}$ of Figure 3. CON, control; WASH, wash period.

like neurons in ganglia 5 and 6 also responded to pinching of the gut wall (second row, right). This finding provides clear evidence that the $\mathrm{N}$ cell in ganglia 5 and 6 is of the $\mathrm{N}_{\text {med }}$ type.

Effects of procaine on single $N$ cells in ganglia 5 and 6 and 20 and 21. The sex ganglia 5 and 6 and the tail ganglia 20 and 21 contain only one neuron pair which has been identified as being a nociceptive cell (McKay et al., 1982). Figures 6 and 7 show that procaine affected the putative $\mathrm{N}$ cells in these two subsets of ganglia differently.

The $\mathrm{N}$ cell in ganglion 5 responded to procaine with small changes in membrane potential; in the example of Figure $6 A, 10 \mathrm{~mm}$ procaine first hyperpolarized the cell 
hy about $3 \mathrm{mV}$ then depolarized it by about $3 \mathrm{mV}$ (top trace). The changes in membrane potential produced in these types of cells were usually in the hyperpolarizing direction. When exposed to concentrations of procaine below that which completely abolished the action potential, the effect of procaine on the single $\mathrm{N}$-like cell was to reduce its amplitude and maximum rate of depolarization. This is shown in Figure $6 B$, which is from a cell in another preparation exposed to $5 \mathrm{mM}$ procaine. The single bilateral $\mathrm{N}$ cells in ganglion 6 responded to procaine, as did the homologous cells in ganglion 5 . Thus, the putative $\mathrm{N}$ cell in ganglia 5 and 6 responded to procaine like the $N_{\text {med }}$ neurons of ganglia 7 to 19 .

In ganglia 20 and 21 , the single $\mathrm{N}$ cell responded to procaine like the $\mathrm{N}_{\text {lat }}$ cells of the midbody region. The typical effect of procaine on this cell type was a dosedependent depolarization and a large prolongation of the action potential, as illustrated in Figure 7. This figure is from two different preparations exposed to $10 \mathrm{mM}$ and 5 $\mathrm{mM}$ procaine, respectively. In the top record, procaine induced a reversible $32-\mathrm{mV}$ depolarization. The action potential evoked in another cell from a different preparation during exposure to $5 \mathrm{mM}$ procaine was greatly prolonged and resembled the one normally seen in the $\mathrm{N}_{\text {lat }}$ (Fig. 3) during procaine exposure. Based on selective labeling of $\mathrm{N}$ cells by monoclonal antibodies, McKay et al. (1982) came to the same conclusions about the identity of the single $\mathrm{N}$ cells in ganglia $5,6,20$, and 21 .

\section{Discussion}

The results presented in this paper demonstrate the existence of qualitative differences in sensitivity to procaine among $\mathrm{N}$ cells of the leech Macrobdella. Since these differences persisted in the presence of elevated $\mathrm{Mg}$ concentrations, they could not have been mediated by chemical synaptic actions. Several other workers have reported that the bilateral pairs of nociceptive sensory neurons present in each segmental ganglion of the leech midbody regions ( 7 to 19) are not identical. The $\mathrm{N}_{\text {lat }}$ and the $\mathrm{N}_{\text {med }}$ cells in Hirudo differ from one another by their receptive fields (Blackshaw et al., 1982) and their extrasynaptic receptors (Sargent et al., 1977), those of $\mathrm{Ma}$ crobdella by their synaptic output (A. L. Kleinhaus and J. Johansen, unpublished observations) and their receptive fields (this study), and those of Haemopis and Hirudo by their selective labeling by monoclonal antibodies (McKay et al., 1982).

Despite subtle differences in morphology found among $\mathrm{N}$ cells in three leech species, the arborization pattern of their axons was very similar-Hirudo (Muller and McMahan, 1976), Haemopis (Keyser and Lent, 1977), Macrobdella (this report). In particular, as shown for Macrobdella in this study, the previously identified N cells in the midbody region were indistinguishable from the putative single $\mathrm{N}$ cells in the specialized ganglia 5 and 6 and 20 and 21. The combined physiological and pharmacological data of this paper and the immunological findings of McKay et al. (1982) indicate that in three species the $\mathrm{N}$ cells in ganglia 5 and 6 are of the $\mathrm{N}_{\text {med }}$ type, whereas those of ganglia 20 and 21 are of the $N_{\text {lat }}$ type. The morphological and immunochemical data suggest that the physiological and pharmacological differ- ences are not artifacts of different neuron cable properties or distribution of conductances over the cell surface, but these possibilities cannot be rigorously excluded.

These results show that opposite actions are exerted by procaine on two subsets of mechanosensory neurons in the leech nervous system. Although procaine exerts many different effects on excitability and metabolic proc esses in other preparations, the membrane potential changes it produced in these cells could be related to its convulsant and anticonvulsant properties in the mammalian central nervous system (Ritchie and Greene, 1980). The antiarrhythmic properties of procaine and related local anesthetics have in part been credited to their ability to increase potassium conductance $(\mathrm{gK})$ in sheep Purkinje fibers (Arnsdorf and Bigger, 1975; Weld and Bigger, 1975). The most likely explanation for the procaine-induced hyperpolarization of $\mathrm{N}_{\text {med }}$ cells is an increase in $\mathrm{gK}$, despite the fact that the change in membrane potential produced by a 10 -fold change in $\mathrm{K}$ concentration was less than that expected for a pure $K$ event. Therefore, it seems plausible that this kind of action might contribute to procaine's anticonvulsant properties in mammalian central nervous system. Failure of producing a reversal of the procaine-induced hyperpolarization by current injection may be related to the cable properties of the membrane and the distant location of the relevant conductances. The transfer of current injected from the soma to the site of action is dependent on the geometry of the cell (Carnevale and Johnston, 1982). The amount of current which can be injected from the soma to the putative drug-sensitive sites will be greater than the amount of current that can be transferred from those to the soma, only in the case of large dendritic dominance. Because of these considerations, the procaine-sensitive conductances do not have to be more than a space constant away in order for them to be unaffected by current injected through a microelectrode at the soma. Furthermore, the drug-sensitive conductances are probably distributed over a region along the cable, unlike the active site of a simple synapse which is essentially a point source. Distributed sites of conductances sensitive to a drug (in this case procaine) will act as a further shunt and decrease the current injected from the soma so that an even smaller fraction thereof will effectively reach them.

It is theoretically possible that the absence of a reversal potential resulted from the presence of opposite changes in conductance to two ionic species (Brown et al., 1971). Under these conditions, there will be no reversal potential only if the sum of the two conductance changes equals zero. In the present experiments, however, membrane conductance was clearly increased in all cases, which makes this explanation unlikely.

The large depolarization produced by procaine in the $\mathrm{N}_{\text {lat }}$ cell could in like manner contribute to the drug's convulsant effects. Other workers reported that procaine and related compounds depolarized mammalian sinoatrial node preparations and myocardial cells in culture (Sperelakis and Lehmkuhl, 1968; Josephson and Sperelakis, 1976; Senami and Irisawa, 1981). Procaine also depolarized smooth muscle cells in a dose-dependent manner (Washizu, 1968). In these studies alterations in 
the ratio of $\mathrm{Na}$ and $\mathrm{K}$ permeabilities were thought to be responsible for the paradoxical effect of local anesthetics. The depolarization observed in response to procaine in certain types of leech cells was Na-dependent, although our results cannot rigorously determine whether the procaine-induced depolarization resulted from a direct increase in $\mathrm{Na}$ conductance or was secondary to a change in the ratios of $\mathrm{Na}$ and $\mathrm{K}$ permeabilities. The current/ voltage relationship for the $\mathrm{N}_{\text {lat }}$ was linear in the range of depolarizations produced by procaine. Furthermore, the conductance increase seen in the presence of the drug could not be accounted for by the drug-induced depolarization alone. These findings suggest that the increase in membrane conductance produced by the drug reflected a true increase in permeability and was not secondary to the change in membrane potential.

Structurally, the tertiary amine procaine is related to acetylcholine (ACh) (Gage, 1976) and can alternatively act as a cholinergic agonist (Israel and Meunier, 1979) and antagonist (Kordas, 1970; Katz and Miledi, 1975; Adams, 1977; Marty, 1978; Neher and Steinbach, 1978). However, since the $\mathrm{N}_{\text {med }}$ and $\mathrm{N}_{\text {lat }}$ in the leech were both depolarized by ACh (Sargent et al., 1977), it seems unlikely that the membrane actions of procaine described in this paper are related to any such action.

This study shows that the pattern of responsiveness exhibited by the two $\mathrm{N}$ cell types is systematic and correlates well with other characteristic features which segregate these neurons into distinct subgroups. Using procaine responsiveness as a criterion, the conclusions reached about the identity of cells which were suspected to be N-like in ganglia 5 and 6 and 20 and 21 agreed well with those obtained by the use of molecular markers, such as monoclonal antibodies. Such results provide support for the hypothesis, evolved from our earlier work, that the orderly variations in pharmacological responsiveness encountered among identified neurons in the leech central nervous system may be related to their function (Kleinhaus and Prichard, 1977, 1983; Kleinhaus, 1980).

\section{References}

Adams, P. R. (1977) Voltage jump analysis of procaine action at frog-endplate. J. Physiol. (Lond.) 268: 291-318.

Anderson, J. M., A. L. Kleinhaus, L. Manuelidis, and J. W. Prichard (1974) Bevelled dual-channel microelectrodes. IEEE Trans. Biomed. Eng. 21: 482485.

Arnsdorf, M. F., and J. T. Bigger (1975) The effect of lidocaine on components of excitability in long mammalian cardiac Purkinje fibers. J. Pharmacol. Exp. Ther. 195: 206-215.

Blackshaw, S. E., J. G. Nicholls, and I. Parnas (1982) Physiological responses, receptive fields and terminal arborizations of nociceptive cells in the leech. J. Physiol. (Lond.) 326: 251260.

Brown, J. E., K. J. Muller, and G. Murray (1971) Reversal potential for an electrophysiologic event generated by conductance changes: Mathematical analysis. Science 174: 318.

Carnevale, N. T., and D. Johnston (1982) Electrophysiological characterization of remote chemical synapses. J. Neurophysiol. 47: 606-621.

Gage, P. W. (1976) Generation of end-plate potentials. Physiol. Rev. 56: 177-247.

Israel, J. M., and J. M. Meunier (1979) Procaine as an acetyl- choline agonist in snail neuron. J. Pharmacol. Exp. Ther. 211: 93-98.

Josephson, I., and N. Sperelakis (1976) Local anesthetic blockade of $\mathrm{Ca}^{2+}$-mediated action potentials in cardiac muscle. Eur. J. Pharmacol. 40: 201-208.

Katz, B., and R. Miledi (1975) The effect of procaine on the action of acetylcholine at the neuromuscular junction. $J$. Physiol. (Lond.) 249: 269-284.

Keyser, K. T., and C. M. Lent (1977) On neuronal homologies within the central nervous system of leeches. Comp. Biochem. Physiol. 58A: 285-297.

Kleinhaus, A. L. (1980) Segregation of leech neurons by the effect of sparteine on action potential duration. J. Physiol. (Lond.) 299: 309-321.

Kleinhaus, A. L., and J. W. Prichard (1975) Calcium dependent action potentials produced in leech Retzius cells by tetraethylammonium chloride. J. Physiol. (Lond.) 246: 351-361.

Kleinhaus, A. L., and J. W. Prichard (1977a) A calcium reversible action of barbiturates on the leech Retzius cell. J. Pharmacol. Exp. Ther. 201: 332-339.

Kleinhaus, A. L., and J. W. Prichard (1977b) Close relation between TEA responses and Ca-dependent membrane phenomena of four identified leech neurones. J. Physiol. (Lond.) 270: 181-194.

Kleinhaus, A. L., and J. W. Prichard (1979) Interaction of divalent cations and barbiturates on four identified leech neurons. Comp. Biochem. Physiol. 63C: 351-357.

Kleinhaus, A. L., and J. W. Prichard (1983) Differential action of tetrodotoxin on identified leech neurons. Comp. Biochem. Physiol. 74C: 211-218.

Kordas, M. (1970) The effect of procaine on neuromuscular transmission. J. Physiol. (Lond.) 209: 639-699.

Marty, A. (1978) Noise and relaxation studies of acetylcholine induced currents in the presence of procaine. J. Physiol. (Lond.) 278: 237-250.

McKay, R., S. Hockfield, J. Johansen, L. Kleina, and I. Thompson (1982) Monoclonal antibodies as probes of the leech nervous system. Soc. Neurosci. Abstr. 8: 714.

Muller, K. J., and U. J. McMahan (1976) The shapes of sensory and motor neurones and the distribution of their synapses in ganglia of the leech: A study using intracellular injections of horseradish peroxidase. Proc. R. Soc. Lond. (Biol.) 194: 481499.

Neher, E., and J. H. Steinbach (1978) Local anesthetics transiently block current through single acetylcholine receptorchannels. J. Physiol. (Lond.) 277: 153-176.

Nicholls, J. G., and D. A. Baylor (1968) Specific modalities and receptive fields of sensory neurones in the CNS of the leech. J. Neurophysiol. 31: 740-756.

Ritchie, M. J., and N. M. Greene (1980) Local anesthetics. In The Pharmacological Basis of Therapeutics, L. S. Goodman and A. Gillman, eds., pp. 300-320, Macmillan, New York.

Sargent, P. B., K. Yau, and J. G. Nicholls (1977) Extrasynaptic receptors on cell bodies of neurons in central nervous system of the leech. J. Neurophysiol. 40: 446-452.

Senami, M., and H. Irisawa (1981) Effect of procaine amide on the membrane currents of the sino-atrial node cells of rabbits. Jpn. J. Physiol. 31: 225-236.

Sperelakis, N., and G. Lehmkuhl (1968) $\mathrm{Ba}^{2+}$ and $\mathrm{Sr}^{2+}$ reversal of the inhibition produced by ouabain and local anesthetics on membrane potentials of cultured heart cells. Exp. Cell Res. 49: 396-410.

Stuart, A. E. (1970) Physiological and morphological properties of motoneurones in the central nervous system of the leech. J. Physiol. (Lond.) 209: 627-646.

Washizu, Y. (1968) Procaine on smooth muscle. Comp. Biochem. Physiol. 27: 121-126.

Weld, F. M., and J. T. Bigger (1975) Effect of lidocaine on the 
early inward transient current in sheep cardiac Purkinje fibres. Circ. Res. 37: 630-639.

Yang, J., and A. L. Kleinhaus (1982) Procaine actions on leech Retzius cells. Soc. Neurosci. Abstr. 8: 252.

Zipser, B. (1982) Complete distribution patterns of neurons with characteristic antigens in the leech central nervous system. J. Neurosci. 2: 1453-1464.

Zipser, B., and R. McKay (1981) Monoclonal antibodies distinguish identifiable neurons in the leech. Nature (Lond.) 289: $549-554$. 